\title{
Venture Capital Networks in Australia: Emerging Structure and Behavioural Implications
}

\author{
Asif Siddiqui ${ }^{1}$, Dora Marinova ${ }^{1} \&$ Amzad Hossain $^{1}$ \\ ${ }^{1}$ Curtin University Sustainability Policy (CUSP) Institute, Curtin University, Perth, Australia \\ Correspondence: Dora Marinova, CUSP, Curtin University, GPO Box U1987, Perth., WA 6845, Australia. Tel: \\ 61-8-9266-9033. E-mail: d.marinova@curtin.edu.au
}

Received: February 5, 2016

Accepted: February 28, 2016 Online Published: April 27, 2016

doi:10.5539/jms.v6n2p21

URL: http://dx.doi.org/10.5539/jms.v6n2p21

\begin{abstract}
Inter-firm collaboration and networking have significantly increased in the context of technological innovation, changing the business environment and contributing to rapid and global integration. Being at the heart of technological innovation and commercialization, the venture capital (VC) industry has adopted inter-firm alliance as a common practice on a global scale. The most common form of collaboration in the industry is investment syndication between firms which eventually leads to a network of syndication. Understanding drivers of syndication and its financial implications is no longer enough. The nature of the inter-firm collaboration networks can be influenced by location and industry characteristics, and in turn they can also influence the industry practices and change. This study investigates the emerging structure of the VC networks in technology ventures in Australia in order to capture key features of the Australian VC market. Using graph theory the paper presents syndication network graphs and analyses their structural properties. The connectivity and density analysis shows further scope for facilitating the flow of information and resources across the VC industry. Behavioural implications of the networks on the industry practices and viability are also analysed and questions raised about the VC industry's contribution to supporting and mainsteaming sustainable technologies.
\end{abstract}

Keywords: syndication network, inter-firm collaboration, industry culture, sustainability

\section{Introduction}

There is a growing evidence around the world of inter-firm networks across manufacturing, service and financial industries, especially in the venture capital (VC) segment of the financial industry (Sydow et al., 1997; Hochberg, Ljungqvist, \& Lu, 2007; Hopp \& Reider, 2011; Terjesen, Patel, Fiet, \& D’Souza, 2013). Collaboration among competing firms within the industry has emerged as a source of information and resource accumulation as well as a competitive advantage (Lado, Boyd, \& Hanlon, 1997; Dyer \& Singh, 1998; Baraldi, Gressetvold, \& Harrison, 2012; Gu \& Lu, 2014). Since the 1980s, this has been particularly accelerated by the rapid technological innovation and commercialization on a global scale which has changed the market frontiers and nature of competition. It is therefore not surprising that researchers have taken a serious interest in the nature and implications of inter-firm collaboration.

However, the nature of inter-firm collaboration is influenced by industry characteristics, such as core business, resources requirement, investment risk, market competition as well as the industry's location which provides the economic, legal and social context for its activities. The VC industry has not only been at the centre of the commercialization of innovation and productivity growth around the world but also at the heart of entrepreneurial finance and financial innovation. Investing in the equities of young and promising technology ventures, managing and growing them to eventually divest the equity holdings at a higher price is the core business of the VC firms which requires industry expertise and also involves a high risk of failure. In response to the unique requirements of the industry's core business, the $\mathrm{VC}$ firms have developed their own pattern of inter-firm alliance and collaboration which usually takes the form of equity syndication. Consequently, this results in the formation of syndication networks connecting the firms through the syndicated ventures. The structure and characteristics of the network then represent the industry as well as the macroeconomic context within which it is located.

Against this background, we investigate the emerging pattern of syndication networks in Australia since the commencement of the country's VC industry in 1984 when the Management \& Investment Companies (MIC) 
Program was launched by the government as an integral part of its industrialization strategy (Forsaith, 1993). The emerging structure of the network has some characteristics unique to Australia, although analytical insights from similar studies elsewhere (Bygrave, 1988; Sorenson \& Stuart 2001; Kogut, Urso, \& Walker, 2007; Zhang, Feng, Zhu, \& Stanley, 2015; Jin, Zhang, \& Li, 2016) are also informative. We also use the literature on inter-firm alliance to further understand the Australian syndication network and its behavioural implications, especially on the industry's viability which emerged as a significant issue because of the vulnerabilities experienced during the global financial crisis (GFC) as well as the industry's growing exposure to the emerging environmental, social and governance (ESG) risks and opportunities.

Therefore the research not only investigates the structural properties of the $\mathrm{VC}$ industry networks with reference to Australia, but also makes a general contribution towards understanding the behavioural implications of the industry network in terms of an integrated platform for standardization and changes of industry practices. The $\mathrm{VC}$ sector is increasingly proving to be a vehicle supporting innovation and new technologies in relatively risky ventures as has been the case with information and computer technologies and biotechnology. More recently, VC firms are expected to explore and assist with opportunities related to climate change and the natural environment, such as renewable energy, nanotechnology, water supply and treatment. With the need to mainstream sustainability in order to achieve fast reduction in greenhouse gas emissions, fair use of resources and environmental conservation, there are high expectations that the entire financial sector, including venture capital, will develop mechanisms and tools to support these new classes of technologies. Individually and collectively through their networks, they have to respond to external environmental and social pressures and embrace forthcoming risks and challenges (Christofi, Christofi, \& Sisaye, 2012).

The subsequent sections of the paper include a literature review which identifies research gaps and establishes the significance and the rationale of the study. This is followed by the empirical investigation in which we use co-investment syndication as a tangible and measurable form of inter-firm alliance in the VC industry and graph theory to present and analyze venture capital investments. In the data and methodology section, the analytical boundary of the study is defined and the relevant VC investment data for Australia to be used in the structural analysis of the collaboration networks are described. Questions related to VC industry's contribution to sustainability are raised. Finally, the last section of the paper links this analysis with the greater collaboration networks among industries, communities and government on the basis of the structural properties of the Australian VC networks which have not been previously explored.

\section{Literature Review}

An extensive multidisciplinary literature on strategic alliances and inter-firm collaboration has emerged in the 1990s especially enriched by the initiative of organizational theorists' quest for understanding socio-behavioural theories and developing insights into organizational behaviour and performances (Dennis, 2000; Stuart, 1998). We utilize insights from this literature to identify gaps in the existing research on VC syndication networks, especially in terms of understanding the behavioural implications of the structural properties of inter-firm collaboration networks which not only integrate the industry but also provide a social platform for cultural changes. The literature on inter-firm collaboration and alliance has investigated various firm-level issues, such as drivers of inter-firm alliance, implications on the firm's performance, contractual and managerial matters. Network resources, including information, technology, know-how and skill, are similar to financial and social capital (Scott \& Davis, 2003; Alexy, Block, Sandner, \& Ter Wal, 2012; Nahata, Hazarika, \& Tandon, 2014) and influence the firms' activities and business orientation.

Researchers have used a range of theoretical premises, such as resource based management, resource dependence and exchange models, transaction cost theory and social exchange theories, to explain different aspects of the inter-firm alliance strategies (Tsang, 1998; Mowery, Oxley, \& Silverman, 1998; Anderson, 1995; Young-Ybarra $\&$ Wiersema, 1999). It has been suggested that there is a comparative advantage in simultaneous competition and cooperation between firms (Lado et al., 1997; Dyer \& Singh, 1998). The network of firms can also create a unique pool of resources which are inimitable and unreplaceable and thereby can be a source of long-term competitive advantage for the participats (Goerzen, 2007). These resources embedded in a rich social network can shape the opportunity set perceived by the firms. The network facilitates and enables firm exchange using social mechanisms (Gulati, 1999; Jones, Hesterly, \& Borgatti, 1997). In a different way, it can then challenge the traditional boundaries of the organizations providing a unique source of competitive advantage as well as an extended strategic space (Stuart, Hoang, \& Hybels, 1999). The networks serve as a platform for knowledge transfer, although some alliances might lead to undesirable outcomes and dilute the competitive advantage (Mohr \& Sengupta, 2002; Knights, Murray, \& Willmott, 1993). 
Collaboration and networking among competing firms can take several forms, both informal and formal. Informal networking can take place in various social and professional events, such as seminars and conferences. The formalization of networks can lead to the formation of professional and industry associations. As there is no prescribed sequence for the formal and informal ways of networking to occur, they can happen simultaneously on multiple platforms. Any formal collaboration may lead to joint financing arrangements which can either be a non-equity or equity alliance (Das \& Teng, 1996; Teece, 1992). The prevalent form of equity alliance among VC firms takes the form of co-investment syndication where two or more $\mathrm{VC}$ firms either invest together at the same time in a company to form a syndicate or one firm invests first and then invites other $\mathrm{VC}$ firms in subsequent rounds of investment (Brander, Amit, \& Antweiler, 2002).

In the co-investment syndicates, the two or more $\mathrm{VC}$ firms investing together in a venture are represented on the company's board and are making joint decisions about its future. Thus, syndication brings VC firms together through board representation and shared objectives (Noyes, Brush, Hatten, \& Smith-Doerr, 2014). The syndicates eventually become units or nodes of the syndication network of the VC firms. As the VC firms can co-invest in multiple ventures with the same or different set of investors, connecting multiples nodes eventually forms the industry networks. The co-investment syndicates in the portfolio companies represent nodes of the network and it commences to be formed at the node. Further nodes within the network may also be facilitated through syndicates.

It has been argued that equity alliance is important for controlling relational risk in a changing competitive environment and integrated market space (Das \& Teng, 1996) and inter-firm strategic alliances are routine in the hi-tech sector in order to facilitate organizational learning, innovation and growth as well as improve corporate reputation (Stuart et al., 1999). The process of technological innovation and entrepreneurship is often supported by coherent institutional innovations in the financial market, especially the VC industry, and the decision to invest in a young and innovative enterprise with little or no revenue track record is associated with high level of uncertainty (Tayebjee \& Bruno, 1984; Bygrave \& Timmons, 1992). Furthermore, as the young ventures mature they often require diverse resources, specialized skills and knowledge which could often be provided better by a pool of VC firms as opposed to one firm. In response to the industry risk environment and resource requirements during the pre- and post-investment phase, inter-firm co-investment syndication has emerged as a regular form of collaboration (Gompers, 1995). The VC literature therefore often explores the question as to why VC firms syndicate and whether this makes any difference to their financial performance.

Bygrave (1987) in his pioneering work on syndication behaviour suggested that the VC firms syndicate to address the uncertainty associated with investment and to access deal information, specialized knowledge and resources which can add value to the portfolio. Lerner (1994) emphasized that information sharing and obtaining a valid second opinion from another experienced VC firm in venture selection can drive syndication. Shane \& Cable (2002) similarly suggest that peer reference in the investor network plays a vital role in the venture selection. Sharing experience, gathering information in the investment decision and reciprocating deals have also been emphasized as important (Casamatta \& Haritchabalet, 2007; Hopp \& Lukas, 2014, Gu \& Lu, 2014). Bygrave (1987), Locket \& Wright (2001), Baraldi et al. (2012) used the resource exchange model and resource based view of firms to explain the syndication decisions. They point out that either pre-investment venture selection or the post-investment value creation can drive the syndication decision. De Clarcq \& Dimov (2004), Manigart et al. (2006) among others argued that syndication is motivated by both investment risk reduction and portfolio risk diversification. However, VC firms can syndicate for more than one reason and research identified both venture selection and value added as motives for syndication (Hopp \& Rieder, 2011).

The factors which motivate syndication also encourage syndication networking as a natural extension. These syndication networks gradually connect VC investors through current and past co-investments and board representations in the shared portfolio companies in a web of relationships (Hochberg et al., 2007). Each venture capitalist would have their individual team of head-hunters, auditors, lawyers, underwriters, investment bankers to support the portfolio companies (Sahlman, 1990). The network members then get to share information, referral and opinion about future deals which help in developing long-term relationships leading to deal reciprocations and identification of future co-investors (Bygrave, 1988; Gompers, 1995; Stuart, 1998; Hop \& Lukas, 2013). Previous research on the impact syndication networks have on the VC firm performances and results often shows positive links measured in terms of successful exit of the portfolio companies as well as internal rate of return on investment (Jääskeläinen, 2012; Guo \& Jiang, 2013). It has been found that syndication can lead to better return and higher shareholder value (Brander et al., 2002; Lehman, 2006; Hochberg et al., 2007; Baraldi et al., 2012) and the network position of VC firms can also enhance their portfolio performance (Hochberg et al., 2007; Abel \& Nisar, 2007; Checkley, Steglich, Angwin, \& Endersby, 2014). 
The structural properties of the firms' networks, such as level and duration of interactions, are influenced by the structure of the industry (Sydow, Van Well, \& Windeler, 1997). These networks defuse information which is both sector and location specific and can be a driver in market integration and expansion (Stuart et al., 1999; Kogut et al., 2007). In other words, the structural properties of the VC networks as well as their implication can often be country and industry specific. There have been studies of VC firm network structures highlighting their properties first in the US (Bygrave, 1988; Kogut et al., 2007) and more recently in Asia (Zhang et al., 2015; Jin et al., 2016). The Australian VC co-investment networks in technology related sectors however have not attracted research interest until now and this study aims to analyse their structural properties.

Furthermore, the literature on inter-firm alliances recognizes the relational, reputational and social aspects with long-term implications, whereas $\mathrm{VC}$ research primarily focuses on financial performances. Nonetheless, the existing VC literature suggests that the venture capitalists who are well-networked, reputable and experienced seem to enjoy a more influential position in the networks (Lerner, 1994; Gu \& Lu, 2014). Terjesen et al. (2013) also argue that normative rationality rooted in the norms and tradition plays a part in the co-investor selection process. In this paper, we analyse the behavioural and non-financial implications of co-investment networks in relation to governance and culture implications of the VC networks, especially on the industry's viability and potential contribution to sustainability priorities. This analysis complements previous research on the implication of networks on financial performance.

\section{Data and Methodology}

This section describes how the current study was conducted, including the nature of the information source used and the adopted methodology for the analysis of the data. The aim is to describe the developments in the Australian VC industry and its preparedness to respond to current expectations and the need for technological changes.

\subsection{Data}

In order to analyse the VC firms' co-investment networks in Australia we use the history of venture capital investment in portfolio companies from 1984 to 2008. This timeframe covers the first 25 years of existence of this industry in Australia since its emergence through government encouragement in 1984. We use the Thomson Reuters' VentureXpert dataset (Venture Economics, 2009) as information source. The relevant data at a company level include VC investment dates and amounts as well as venture stage and investment industry. At the level of the VC firm, profile information including firm size and investment preferences is also available and extracted. The dataset classifies all companies in three broad industry categories, namely information and communication technology (ICT), biotechnology, medical and healthcare (BMH) and other non-high-tech sectors. Since VC in essence is the development capital for technology ventures, we consider such investments to include early (seed and start-up) and expansion stages in the ICT and BMH sector, leaving out all later stage private equity related investments. We then analyse the respective VC co-investment network in these two industries separately and compare them considering their different nature.

During the observation period 1097 technology ventures received VC investments of which $92 \%$ took place after 1998. This is reflective of a very slow growth of the VC market in the first one and a half decades of its existence. Despite strong government support, according to Lerner \& Watson (2008) not all programs paid off as desired due to inappropriate tax incentives and inefficient regulatory regime. While the early government efforts failed to generate sufficient investment for technology related companies and young enterprises (Golis et al., 2010), later initiatives such as the Innovation Investment Fund (IIF) program produced trained VC fund managers strengthening the market forces (Cumming, 2007). As the market matured, VC investment started to experience a relatively significant growth which can be explained by the gradual shift from dependence on government support to establishment of market forces. Since 1998, reportedly 646 companies received venture capital finance from $126 \mathrm{VC}$ firms where 53 of them were corporate venture organizations and affiliates of financial institutions, 62 were private equity firms raising finances independently from pension funds, endowment funds, angel and individual investors and 11 were government VC programs and business incubators (refer to Table 1). 
Table 1. Venture related investment in Australia, 1980-2008

\begin{tabular}{|c|c|c|c|c|}
\hline \multirow[t]{2}{*}{ Industry } & \multicolumn{2}{|c|}{ Ventures 1980-2008 } & \multicolumn{2}{|c|}{ Ventures 1998-2008 } \\
\hline & Total & Percentage & Total & Percentage \\
\hline $\begin{array}{l}\text { Information and } \\
\text { communication technology } \\
\text { (ICT) }\end{array}$ & 386 & $35.19 \%$ & 361 & $35.64 \%$ \\
\hline $\begin{array}{l}\text { Biotechnology, medical and } \\
\text { healthcare }(\mathrm{BMH})\end{array}$ & 183 & $16.68 \%$ & 173 & $17.08 \%$ \\
\hline Other & 528 & $48.13 \%$ & 479 & $47.29 \%$ \\
\hline Total & 1097 & & 1013 & \\
\hline
\end{tabular}

\subsection{Methodology}

For the empirical investigation to follow, we define syndication as two of more VC firms co-investing in a portfolio company at any point during the early and expansion stage which are also connected through representation on the board and shared objectives of developing the venture toward a successful exit. The first $\mathrm{VC}$ investor is considered to be the lead investor or initiator. If there are two or more investors co-investing in the first external round of financing at the same date as registered in the dataset, they all can be considered as lead initiators. The VC investors which join the initiator(s) in subsequent round/s are defined as followers. If a VC investor exits as another one enters, they are not considered as co-investors. Thus, we use the portfolio companies as the observation point and record the VC investment dates and investors' profile to identify syndication. Graph theory is then applied to analyse the co-investment networks which are interpreted as graphs (Wasserman, 1994; Hanneman \& Riddle 2005; Borgatti, Everett, \& Freeman, 2002). The rationale for using graph theory is based on both its relevance and analytical versatilities for analysing business networks (Kildaff \& Brass, 2003). The presentation of co-investments as nodes in the network graph first facilitates the users to visualize the network connectivity which allows the identifying of opportunities to enhance resource and information flows in the industry while closing the structural holes. Second, it allows the user to analyse the formation of each node by interpreting the characteristics of the participants. Graph theory helps represent and analyze connectivity between different players and is applicable to many real-world situations (Bondy \& Murty, 1982).

Specifically, the co-investment networks of VC firms are analysed as affiliation networks where both, the portfolio companies and VC firms, are treated as nodes of the graph. The affiliation networks are 2-mode networks with only one set of actors and the second mode being a set of events in which the actors participate the $\mathrm{VC}$ firms are the actors and the portfolio company in which they co-invest is the event. Hence, the actors are linked through participation in the same event. The companies where co-investments take place are the units of observation or the affiliation variables in the graph. All events are defined based on group of actors, not on pairs. Each affiliation therefore is defined as a subset of actors. The VC firms as actors form a tie or create a link with one another when they co-invest in the same company as an event. Consequently, the set of VC firms co-investing in a company forms the co-investment network.

The graphs are derived from the construction of the affiliation matrix $A$ where an element is defined as:

$$
a_{i j}=\left\{\begin{array}{l}
1 \text { if the actor } i \text { is affiliated with the event } j \\
0 \text { otherwise }
\end{array}\right.
$$

Specific codes are generated for each VC firm and portfolio company separately for the BMH and ICT industries. Two affiliation matrices are constructed for them in order to generate separate graphs for these industries. The summation of row elements of each matrix represents the number of co-investments by a VC firm and the summation of the column elements gives the number of investors in a company. Using these matrices, we generate the bipartite-affiliation matrices which provide an overview of the networks in a tabular form. The matrix is symmetric on both sides of the diagonal and the rows/columns show the $i^{\text {th }} \mathrm{VC}$ firm's co-investment number with $j^{\text {th }} \mathrm{VC}$ firm. As at the diagonal points $i=j$, the diagonal elements of the matrix show the $i^{\text {th }} \mathrm{VC}$ firm's total number of co-investments indicating its network position. Then the affiliation networks are generated as a graph for each industry. The graph is defined on a set of nodes representing the VC firms and a set of links representing the co-investment ties. This also allows to identify the key players with higher co-investment ties and generate their ego-networks for further analysis. 


\section{Structural Analysis}

This section analyzes the structural characteristics of the Australian VC networks for the two industries based on their graphs. After examining the network structure, we focus on repeat syndication and other structural characteristics which are of particular interest in understanding how the VC industry operates, and finally we discuss how informative the Australian case is in respect to other economies.

\subsection{Network Structure}

The derived graphs of the VC firms' co-investment networks in the ICT and BMH industry sectors are visually presented in Figure 1 and 2 respectively. All actor VC firms are shown as round dot nodes in the network and the portfolio companies which connect and affiliate with them are presented as square nodes. These affiliation network graphs thus not only show the links among the VC firms but also the shared portfolios. They allow the following properties of the networks to be observed. First, in both industries there is a peripheral spread of direct and indirect ties binding the actors in compact networks; nevertheless in both industries there are small fragments which are not connected with the larger networks. This means that we observe more $\mathrm{VC}$ actors who are well-connected but also some who are making less use of co-investment opportunities. Second, the networks are not particularly dense. This potentially leaves several structural holes restricting the flow of information and resources but also provides opportunities for creating bridges and enhancing the collaboration within the industries.

As the graphs were generated using data about the Australian VC firms' investments in technology ventures, they depict the specific characteristics of the Australian VC market. The networks of both ICT and BMH industries share a common feature, namely they concentrate around a few key players who exhibit a much higher degree of centrality compared to the others. Figure 3 specifically shows the network concentrations around the central players in each industry. There are four central players in the BMH sector: V15 - an independent private equity firm with $\$ 370$ million under management specializing in the BMH since 1996; V25 - a government affiliated VC program operating since 1992 to support the growth of early stage bio-tech ventures; V33 - a financial institute affiliate investment vehicle with a focus on the BMH sector operating since 2004 and managing a relatively smaller size of capital; and V43 - a university affiliated program with a capital size of less than US\$20 million under management investing since 2000. The five central players in the ICT sector include four independent private equity firms and one financial institute affiliated investment vehicle: V5 - a very large financial institute affiliate firm managing around US\$2 billion which has been in the market since 1987; V8 one of the oldest market players since 1984 which manages around US\$235 million; V38 and V19 - in the market since 1996 and 1998 respectively, and V29 - operating since 2001 which manages around US\$116.8 million with a central position in the network. Overall, the central players in the ICT network are relatively older and larger. This is partially because the ICT sector has been the key industry for VC investors before the BMH industries emerged as attractive opportunities. Government and university programs are still playing a key role in the BMH network contributing to the sector's growth while this is not the case with ICT. It is realistic to expect that as other new technological sectors appear, such as those related to renewable energy and other environmental technologies, they will start attracting the attention of the $\mathrm{VC}$ sector but favourable conditions, such as government incentives, would need to be put in place for this to occur.

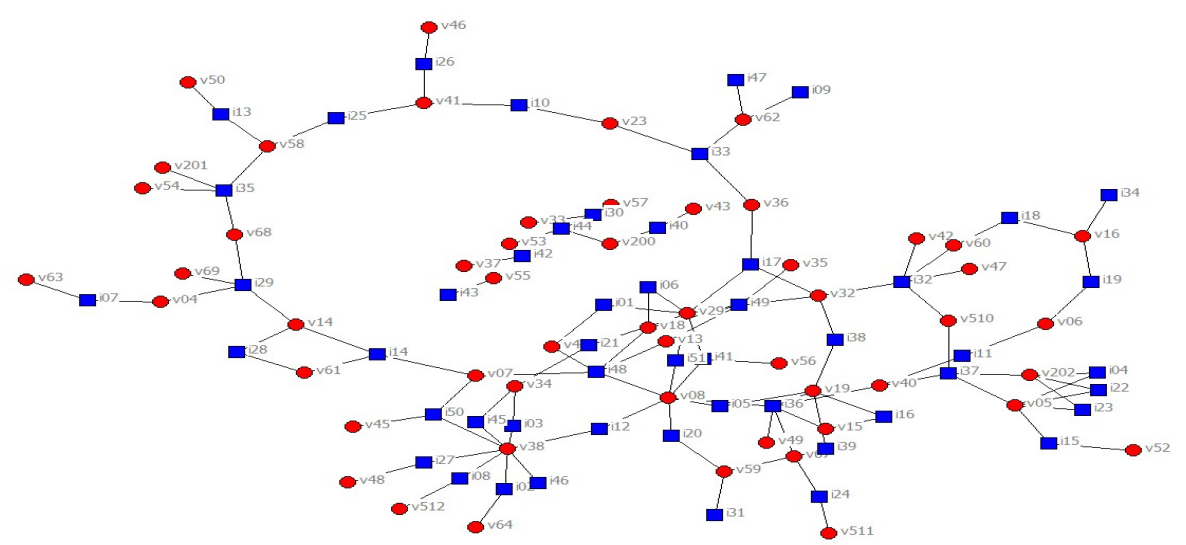

Figure 1. Venture capital firms' co-investment network in the biotechnology, medical and healthcare industry, Australia, 1980-2008

Note. Red dot node - depicts an Australian venture capital firm; blue square node - depicts a venture capital portfolio company. 


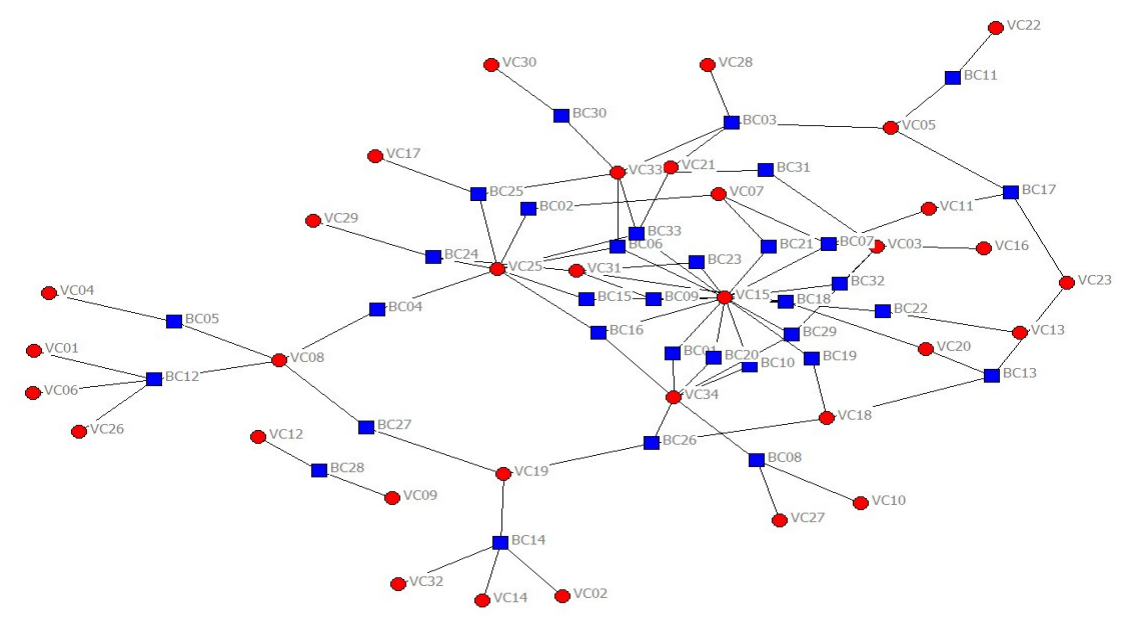

Figure 2. Venture capital firms' co-investment network in the information and communication technologies industry, Australia, 1980-2008

Note. Red dot node - depicts an Australian venture capital firm; blue square node - depicts a venture capital portfolio company.
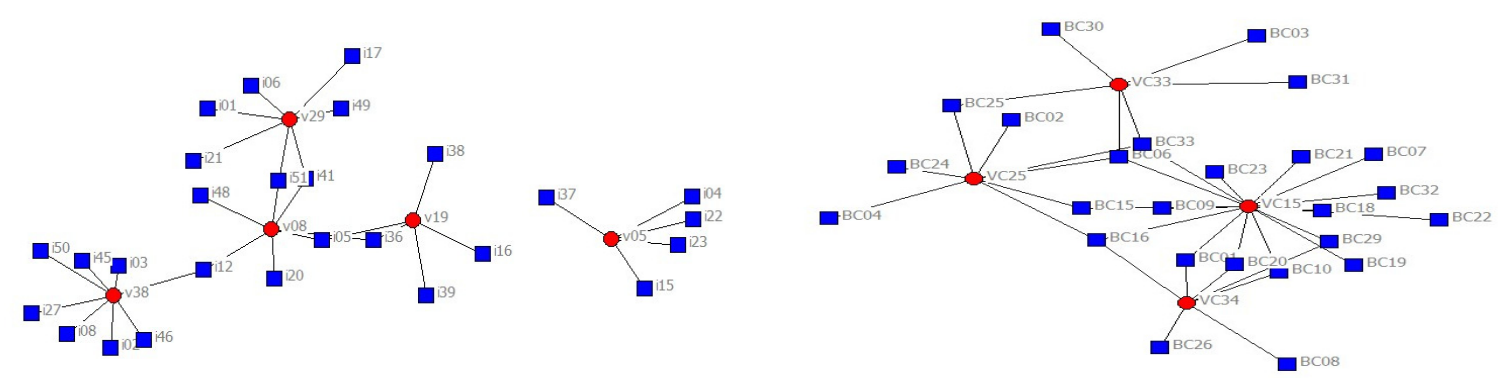

Figure 3. Central venture capital players in the biotechnology, medical and healthcare (left) and information and communication technologies (right) industries, Australia, 1980-2008

Note. Red dot node - depicts an Australian venture capital firm; blue square node - depicts a venture capital portfolio company.

\subsection{Repeat Syndication}

The literature on $\mathrm{VC}$ syndication has often looked at the rationale for syndication within a single period framework, whereas in some cases this can be better justified in a multi-period set-up. With the strength of ties between VC companies ranging from weak to strong, this can be measured by the frequency of communication and repeat co-investments over time. Each VC firm's syndicated portfolio can be observed from the affiliation matrix. The co-investment networks show that there are several coherent subgroups which tend to continue syndicating investments in two or more portfolio companies. For simplicity, we identify subgroups in pairs of two $\mathrm{VC}$ firms co-investing in more than one company over time. For example, if two firms $\mathrm{V}_{1}$ and $\mathrm{V}_{2}$ co-invest in company $C_{1}$ in period $T_{1}$ and then in company $C_{2}$ in period $T_{2}$ and so on, they are considered forming a subgroup in the network through repeat co-investments. This repetition is most likely motivated by positive experiences and possibilities for working together in similar ventures. The findings on repeat co-investments are summarized in Table 2 and 3 for the BMH and ICT sector respectively. 
Table 2. Repeat venture capital co-investments in the biotechnology, medical and healthcare industry, Australia, 1980-2008

\begin{tabular}{lll}
\hline Frequency & Number of Pairs & Pair Description \\
\hline 5 & 1 & $(\mathrm{~V} 15, \mathrm{~V} 34)$ \\
4 & 1 & $(\mathrm{~V} 15, \mathrm{~V} 25)$ \\
3 & 2 & $(\mathrm{~V} 15, \mathrm{~V} 31),(\mathrm{V} 33, \mathrm{~V} 25)$ \\
2 & 4 & $(\mathrm{~V} 15, \mathrm{~V} 33),(\mathrm{V} 21, \mathrm{~V} 33)$, \\
& & $(\mathrm{V} 15, \mathrm{~V} 7),(\mathrm{V} 15, \mathrm{~V} 3)$ \\
\hline
\end{tabular}

Table 3. Repeat venture capital co-investments in the information and communication technologies industry, Australia, 1980-2008

\begin{tabular}{lll}
\hline Frequency & Number of Pairs & Pair Description \\
\hline 4 & 1 & $(\mathrm{~V} 202, \mathrm{V05})$ \\
2 & 9 & $(\mathrm{~V} 38, \mathrm{~V} 34),(\mathrm{V} 19, \mathrm{~V} 08),(\mathrm{V} 8, \mathrm{~V} 29),(\mathrm{V} 13, \mathrm{~V} 18),(\mathrm{V} 14$, \\
& $\mathrm{V} 61),(\mathrm{V} 19, \mathrm{V15})$, \\
& $(\mathrm{V} 18, \mathrm{~V} 29),(\mathrm{V} 29, \mathrm{V32}),(\mathrm{V} 34, \mathrm{~V} 29)$ \\
\hline
\end{tabular}

In the BMH network (refer to Table 2), V15 has two regular co-investment partners, namely V34 and V25. While V15 is a large size independent private equity firm, V34 and V25 are relatively small specialized VC firms affiliated with university research and government support programs. The relationship can be based on complementarity of recourses and expertise. In the ICT network (refer to Table 3), there are fewer repeat co-investments while V202 and V5 have repeated co-investments in four portfolio companies - V5 is a financial institute affiliate VC firm with a size of capital under management close to US\$2 billion while V202 is also a financial institute affiliate firm with a smaller size of capital but with specialization in the ICT sector. The relation can be based on complementarity of resources as well as compatibility of culture (Sarkar, Echambadi, Cavusgil, \& Aulakh, 2001). This pair also shows that prior financial industry networks between the investors can lead to long-term relationships.

There are several VC firms with no specific industry focus which have co-investment relationships with other VC firms in both the ICT and BMH networks. Within the observations dataset, 70.17\% of the co-investments in the ICT networks were done among firms with the same industry preferences while the rest have a record of investing in BMH. Similarly, we observe that 50\% of the co-investing in the BMH network was done by VC firms with preference for the same industry while the other 50\% invest also in ICT industry. The VC firms which are investing across industries are either financial investors with no industry preference or firms with large management teams and multiple expertise.

\subsection{Other Structural Properties}

In the observation dataset, out of $121 \mathrm{BMH}$ companies $27.27 \%$ received syndicated investments and out of 246 ICT companies only $21.14 \%$ received syndicated investment. In the ICT sector, $70.17 \%$ of the VC firms syndicating investment specialize in this industry with the remaining syndicated investments being both in ICT and BHM. The average size of the syndicates in the BMH industry is 2.61 while it is 2.37 in ICT which shows a greater tendency to syndicate investments in the biomedical and health industry. The duration of syndicates however is short and the size of syndicates is small. This could pertain to the overall size and maturity of the Australian venture capital market.

The duration of the co-investment relationship is often limited to a few rounds. Figure 4 shows that in the ICT network most syndication is done for one round and only a very few co-investment relationships go beyond three rounds. One possible explanation is that the $\mathrm{VC}$ firms tend not to invest in very early stages with a longer investment horizon. This is consistent with the nature of investing by VC companies as many of them are private equity firms or financial institute affiliate vehicles. The pattern is similar in the BMH network although most VC firms there tend to maintain syndication relationships for two or more rounds. This network represents a larger variety of investors with different strategic orientations. The size of the syndicates is fairly small and in both networks the majority of syndicates are formed by only two VC firms as shown in Figure 5. Similarly, in both industries most VC firms participated in a syndication only once and a very few more than three times (as shown in Figure 6). Thus, the level of networking is yet to intensify which could in turn increase the density of network ties. 


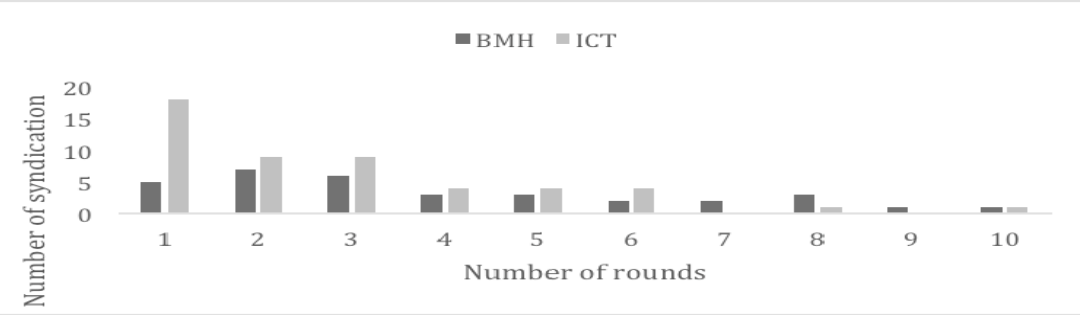

Figure 4. Duration of syndication by number of rounds in the biotechnology, medical and healthcare (BMH) and information and communication technologies (ICT) industries, Australia, 1980-2008

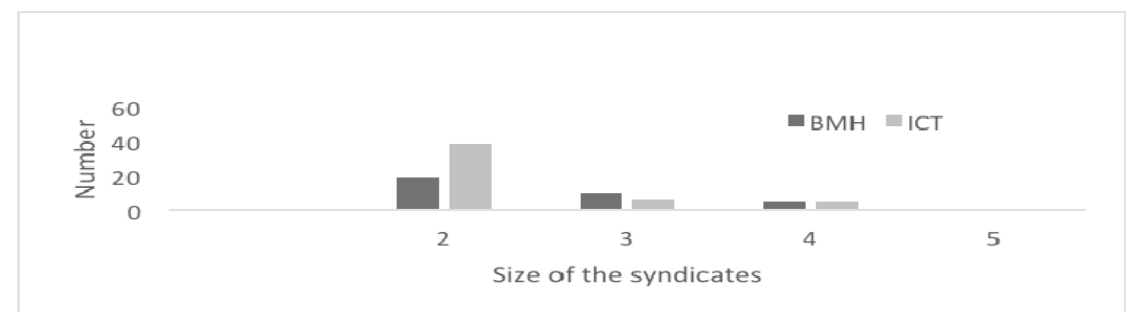

Figure 5. Number of venture capital firms per venture in the biotechnology, medical and healthcare (BMH) and information and communication technologies (ICT) industries, Australia, 1980-2008

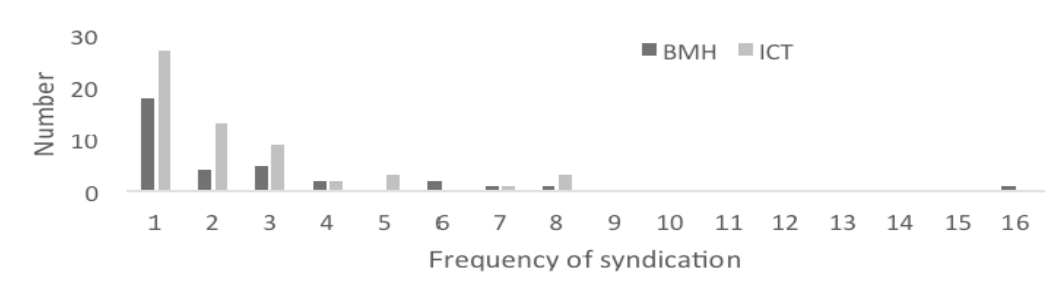

Figure 6. Number of syndicate participation by venture capital firms in the biotechnology, medical and healthcare (BMH) and information and communication technologies (ICT) industries, Australia, 1980-2008

\subsection{Australian Findings}

Networks are a platform for change and the Australian example with the two high-tech industries shows a particular case of risk minimization, flow of information, syndication, repeat investment and other characteristics of the VC industry. Compared to other developed parts of the world, such as USA and Europe, the Australian venture capital industry is much younger and smaller not only in terms of the number of operating firms but also with respect to the size of $\mathrm{VC}$ funds available for investing.

Although each national VC sector is unique and highly influenced by the environment in which it operated, including government regulations, the methodological approach taken in this study is universally applicable. The graph theory allows to illustrate the structural characteristics of the VC industry, describe its properties, identify the main players and analyze the main vehicles for investment, including syndication and repeat co-investment. It can also be used to shed light on opportunities for building further potential and facilitating information flows and resource utilization.

They graph theory analysis also shows that there is a network momentum which means that once some VC firms start investing in particular technologies, others are likely to follow encouraged by syndication and co-investent. This expands the size of the new industry and improves the chances for technological innovation. This network property is important for any emerging new areas, such as companies interested in and motivated by sustainability priorities. The section to follow explores further the behavioural and sustainability implications of VC networks. 


\section{Behavioural Implications and Sustainability}

The above graphs visualize well several structural properties of the networks, including connectivity and density. In a dense network, the flow of information becomes more fluid and the available formations become more homogeneous (Borgatti \& Foster, 2003). A straightforward observation is that the derived networks for the Australian BMH and ICT sectors are not dense and there is scope for increased connectivity which can optimize the flow of information and resources in each network. Other structural properties, such as the size of syndicates, length of syndication relationships, coherent subgroups involved in repeat syndication and characteristics of the central players in each network, shed further light on the socio-behavioural elements within the Australian VC market. The perceived economic benefit of inter-firm networking in the VC industry is captured in terms of contribution to successful divestment of portfolio companies and increased internal rate of return (IRR) on investments (Jaaskelainen, 2012), although the management of syndicated portfolio entails additional transaction cost and potential complications (Wright \& locket, 2003).

While the syndication relationships are initially formed with the aim of maximizing the risk-adjusted financial returns, social variables like trust and reputation play an important part in selecting co-investment partners which in turn may affect the financial performance (Tykvova, 2007; Casamatta \& Hritchabalet, 2007; Fachrunnisa, 2012; Nahata, 2008). The network also requires maintaining the relation and reputation which is critical for creating and transforming value within firms (Madhock \& Tallman, 1998). Thus, co-investment relationships and network participation become a source of relational and social capital in the industry and this has two broad socio-behavioural implications, especially for their viability. First, the network not only serves as a forum for exchanging information and resources but also as a platform for shaping industry practices and culture. Second, the industry networks become a basis for interacting with other institutions. This can lead to greater collaboration within industries, communities and governments essential for a balanced economic and socio-environmental development.

In the high-risk environment of the $\mathrm{VC}$ industry, equity syndication emerges as one of the most common practices. Nonetheless, the approach to risk management especially in the financial industry has become more homogeneous and instrumental over the years while ignoring or underestimating the behavioural risk (Roeschmann, 2014). Meanwhile in recent decades, speculative behaviour, aggressive attitude and short-term orientation have emerged as a new culture in the financial industry (Chappe, Semmler, \& Nell, 2013). This has severely destabilized the VC industry, particularly in relation to events such as the global financial crisis (Block $\&$ Sandner, 2009). In response, there have been calls for changing the culture of risk and relevant industry practices.

At the same time, there has been a growing demand for sustainable and responsible investments which require the $\mathrm{VC}$ firms to be more vigilant about the environmental, social and governance (ESG) risk and opportunities (Christofi, Christofi, \& Sisaye, 2012). However, such changes require industry-wide coordination where networks can be the suitable forum for discussion and transmission of information (Wasserman, 1994; Mizruchi, 1992) and thus become a platform for the transformation of the industry practices and culture. There is growing evidence that industries are developing codes to address external problems and industry associations can work on developing appropriate ESG and sustainability programs (Paton, 2006; Strandberg Consulting, 2013).

Working alone cannot solve many of the complex problems while networking can initiate partnerships and collaboration. This has been recognized as a way to achieve sustainability, although a wider inter-sectoral collaboration between government, industry and community is often called for (Pezzey, 1992; Paton, 2006; Petzel, 2010; Dienhart, 2010). Such a multi-sector collaboration can be more comprehensible and meaningful when some semi-formal or informal industry governance exists in the form of industry associations or equity alliance networks which represent actual investment interest and practices. Resource dependence and social network theory are useful in understanding cross-sectoral collaboration as much as inter-firm collaboration (Nielson \& Thomsen, 2011). Any sustainability norms and standards must take shape within the industry sectors in order to achieve effective cross-sectoral collaborations.

Our data reveals that government, banks, corporations and universities formed different investment vehicles beside traditional private equity funds to invest in young and prospective technology companies in Australia. In the BMH network the central players represent independent private equity firms, government and university programs as well as affiliates of financial institutes. This further reveals that the intricacy of cross-sectoral collaboration is embedded within the VC syndication industry network. Similar collaboration and initiatives by government and industry stakeholders in the future could lead to the next wave of innovation especially in the emerging area of clean technologies. Although still remaining substantially small, environmental technologies are 
likely to be a significant industry sector for future VC investors (AVCAL, 2009; Australian Cleantech, 2015). This is consistent with the global growth in renewable technologies which increased from US\$ 45.1 billion in 2004 to US\$ 270.2 billion in 2014 (UNEP, 2015). It is important to understand that the institutions and culture of the country strongly influence the development of the VC industry in the long run (Cumming, 2007; Nahata et al., 2014).

\section{Conclusion}

Using graph theory, this study set up to analyse the structural and behavioural characteristics of the Australian $\mathrm{VC}$ sector for the first 25 years of its existence. The findings show that firms are simultaneously competing and collaborating with others in an industry which expands the traditional frontiers of strategies. This allows them to address emerging challenges and opportunities resulting primarily from rapid changes in technological possibilities and growing integration in the global market space. The VC industry has been at the forefront of technological innovation in both, ICT and BMH, and is likely to have a similar catalytic role for any upcoming new industries, such as those related to sustainability imperatives. Globalization and thereby collaboration among $\mathrm{VC}$ firms are co-evolving with the market. Syndication in particular is a visible, tangible and measurable form of inter-firm collaboration in the VC industry which has also emerged as a standard industry practice. The industry structure is the outcome of activities and relationships between firms leading to continuous interaction between network and industry structures.

This structural analysis of the VC syndication network in Australia has several behavioural and policy implications for the industry and academia. Network structure based on graph theory can be used for understanding the extent of market integration and intensity of resource flows. It revealed several areas where the connectivity among firms could develop further and this can be facilitated by initiatives from industry practitioners as well as by targeted public policy. While such structural issues are more specific to Australia, the behavioural implications of the network analysis in this paper can be used across the market. The industry must co-evolve with the socio-environmental changes to stay resilient, viable and powerful in facilitating innovation. However, further research and investigation through networks are needed in the future to operationalize the changes in industry practices and culture in order to understand how it responds not only to financial opportunitites but also to new environmental, social and governance priorities.

\section{Acknowledgments}

The second author acknowledges financial help from the Australian Research Council. All authors want to thank the Journal's Editor and anonymous referees whose useful and constructive comments helped improve the quality of the paper.

\section{References}

Abell, P., \& Nisar, T. M. (2007). Performance effects of venture capital firm networks. Management Decision, 45(5), 923-936. http://dx.doi.org/10.1108/00251740710753729

Alexy, O. T., Block, J. H., Sandner, P., \& Ter Wal, A. L. (2012). Social capital of venture capitalists and start-up funding. Small Business Economics, 39(4), 835-851. http://dx.doi.org/10.1007/s11187-011-9337-4

Anderson, J. C. (1995). Relationships in business markets: exchange episodes, value creation, and their empirical assessment. Journal of the Academy of Marketing Science, 23(4), 346-350. http://dx.doi.org/10.1177/009207039502300415

Australian Cleantech. (2015). Australian clean tech review 2015. Retrieved from http://www.auscleantech.com.au/PDF/other/reports/ACR15\%20PUBLISHED\%20EXEC\%20SUMMARY.p df

Australian Private Equity \& Venture Capital Association (AVCAL). (2009). Cleantech PE \& VC. Retrieved from https://www.avcal.com.au/documents/item/44

Baraldi, E., Gressetvold, E., \& Harrison, D. (2012). Resource interaction in inter-organizational networks: Foundations, comparison, and a research agenda. Journal of Business Research, 65(2), 266-276. http://dx.doi.org/10.1016/j.jbusres.2011.05.030

Block, J., \& Sandner, P. (2009). What is the effect of the financial crisis on venture capital financing? Empirical evidence from US Internet start-ups. Venture Capital, 11(4), 295-309. http://dx.doi.org/10.1080/13691060903184803

Bondy, J. A., \& Murty, U. S. R. (1982). Graph theory with applications. New York, NY: North Holland. 
Borgatti, S. P., \& Foster, P. C. (2003). The network paradigm in organizational research: A review and typology. Journal of management, 29(6), 991-1013. http://dx.doi.org/10.1016/S0149-2063(03)00087-4

Borgatti, S. P., Everett, M. G., \& Freeman, L. C. (2002). Ucinet for Windows: Software for social network analysis. Retrieved from https://sites.google.com/site/ucinetsoftware/

Brander, J. A., Amit, R., \& Antweiler, W. (2002). Venture-capital syndication: Improved venture selection vs. the value-added hypothesis. Journal of Economics \& Management Strategy, 11(3), 423-452.

Bygrave, W. D. \& Timmons, J. A. (1992). Venture capital at the crossroads. Boston, MA: Harvard Business School Press.

Bygrave, W. D. (1987). Syndicated investments by venture capital firms: A networking perspective. Journal of Business Venturing, 2(2), 139-154. http://dx.doi.org/10.1016/0883-9026(87)90004-8

Bygrave, W. D. (1988). The structure of the investment networks of venture capital firms. Journal of Business Venturing, 3(2), 137-157. http://dx.doi.org/10.1016/0883-9026(88)90023-7

Casamatta, C., \& Haritchabalet, C. (2007). Experience, screening and syndication in venture capital investments. Journal of Financial Intermediation, 16(3), 368-398. http://dx.doi.org/10.1016/j.jfi.2007.03.003

Chappe, R., Semmler, W., \& Nell, E. (2013). The US financial culture of risk. Constellations, 20(3), 422-441. http://dx.doi.org/10.1111/1467-8675.12050

Checkley, M., Steglich, C., Angwin, D., \& Endersby, R. (2014). Firm performance and the evolution of cooperative interfirm networks: UK venture capital syndication. Strategic Change, 23(1-2), 107-118. http://dx.doi.org/10.1002/jsc.1963

Christofi, A., Christofi, P., \& Sisaye, S. (2012). Corporate sustainability: historical development and reporting practices. Management Research Review, 35(2), 157-172. http://dx.doi.org/10.1108/01409171211195170

Cumming, D. (2007). Government policy towards entrepreneurial finance: Innovation investment funds. Journal of Business Venturing, 22(2), 193-235. http://dx.doi.org/10.1016/j.jbusvent.2005.12.002

Das, T. K., \& Teng, B. S. (1996). Risk types and inter-firm alliance structures. Journal of management studies, 33(6), 827-843. http://dx.doi.org/10.1111/j.1467-6486.1996.tb00174.x

De Clercq, D., \& Dimov, D. (2004). Explaining venture capital firms' syndication behaviour: a longitudinal study. Venture Capital, 6(4), 243-256. http://dx.doi.org/10.1080/1369106042000277688

Dennis, C. (2000). Networking for marketing advantage. Management Decision, 38(4), 287-292. http://dx.doi.org/10.1108/00251740010371757

Dienhart, J. W. (2010). Sustainability, cross-sector collaboration, institutions, and governance. Business Ethics Quarterly, 20(4), 725-728.

Dyer, J. H., \& Singh, H. (1998). The relational view: cooperative strategy and sources of interorganizational competitive advantage. Academy of Management Review, 23(4), 660-679.

Fachrunnisa, O. (2012). Trust, self-regulation and social movement: partner selection at digital collaboration network for SME's sustainability. International Journal of Trade, Economics \& Finance, 3(6), 412-420.

Forsaith, D. M. (1993). Venture capital in Australia: the MIC program and subsequent developments. Small Enterprise Research, 2(1-2), 36-51. http://dx.doi.org/10.5172/ser.2.1-2.36

Goerzen, A. (2007). Alliance networks and firm performance: the impact of repeated partnerships. Strategic Management Journal, 28(5), 487-509.843. http://dx.doi.org/10.1002/smj.588

Golis, C. C., Mooney, P. D., \& Richardson, T. (2010). Enterprise and venture capital: a business builders' and investors' handbook. Sydney, Australia: Allen \& Unwin.

Gompers, P. A. (1995). Optimal investment, monitoring, and the staging of venture capital. The Journal of Finance, 50(5), 1461-1489. http://dx.doi.org/10.1111/j.1540-6261.1995.tb05185.x

Gu, Q., \& Lu, X. (2014). Unraveling the mechanisms of reputation and alliance formation: A study of venture capital syndication in China. Strategic Management Journal, 35(5), 739-750. http://dx.doi.org/10.1002/smj.2117

Gulati, R. (1999). Network location and learning: the influence of network resources and firm capabilities on alliance formation. Strategic Management Journal, 20(5), 397-420.

Guo, D., \& Jiang, K. (2013). Venture capital investment and the performance of entrepreneurial firms: evidence 
from China. Journal of Corporate Finance, 22, 375-395. http://dx.doi.org/10.1016/j.jcorpfin.2013.07.001

Hanneman, R. A., \& Riddle, M. (2005). Introduction to social network methods. Sociology Department, University of California, Riverside. Retrieved from http://faculty.ucr.edu/ hanneman/

Hochberg, Y. V., Ljungqvist, A., \& Lu, Y. (2007). Whom you know matters: venture capital networks and investment performance. The Journal of Finance, 62(1), 251-301. http://dx.doi.org/10.1111/j.1540-6261.2007.01207.x

Hopp, C., \& Lukas, C. (2014). A signaling perspective on partner selection in venture capital syndicates. Entrepreneurship Theory and Practice, 38(3), 635-670. http://dx.doi.org/10.1111/etap.12023

Hopp, C., \& Rieder, F. (2011). What drives venture capital syndication? Applied Economics, 43(23), 3089-3102. http://dx.doi.org/10.1080/00036840903427257

Jääskeläinen, M. (2012). Venture capital syndication: synthesis and future directions. International Journal of Management Reviews, 14(4), 444-463. http://dx.doi.org/10.1111/j.1468-2370.2011.00325.x

Jin, Y., Zhang, Q., \& Li, S. P. (2016). Topological properties and community detection of venture capital network: evidence from China. Physica A: Statistical Mechanics and Its Applications, 442, 300-311. http://dx.doi.org/10.1016/j.physa.2015.09.029

Jones, C., Hesterly, W. S., \& Borgatti, S. P. (1997). A general theory of network governance: exchange conditions and social mechanisms. Academy of Management Review, 22(4), 911-945.

Kilduff, M., \& Brass, D. J. (2010). Organizational social network research: core ideas and key debates. The Academy of Management Annals, 4(1), 317-357. http://dx.doi.org/10.1080/19416520.2010.494827

Knights, D., Murray, F., \& Willmott, H. (1993). Networking as knowledge work: a study of strategic interorganizational development in the financial services industry. Journal of Management Studies, 30(6), 975-995. http://dx.doi.org/10.1111/j.1467-6486.1993.tb00475.x

Kogut, B., Urso, P., \& Walker, G. (2007). Emergent properties of a new financial market: American venture capital syndication, 1960-2005. Management Science, 53(7), 1181-1198. http://dx.doi.org/10.1287/mnsc.1060.0620

Lado, A. A., Boyd, N. G., \& Hanlon, S. C. (1997). Competition, cooperation, and the search for economic rents: a syncretic model. Academy of Management Review, 22(1), 110-141.

Lehmann, E. E. (2006). Does venture capital syndication spur employment growth and shareholder value? Evidence from German IPO data. Small Business Economics, 26(5), 455-464. http://dx.doi.org/10.1007/s11187-005-5599-z

Lerner, J. (1994). The syndication of venture capital investments. Financial Management, 16-27. http://dx.doi.org/10.2307/3665618

Lerner, J., \& Watson, B. (2008). The public venture capital challenge: the Australian case. Venture Capital, 10(1), 1-20. http://dx.doi.org/10.1080/13691060701605538

Madhok, A., \& Tallman, S. B. (1998). Resources, transactions and rents: managing value through interfirm collaborative relationships. Organization Science, 9(3), 326-339. http://dx.doi.org/10.1287/orsc.9.3.326

Manigart, S., Lockett, A., Meuleman, M., Wright, M., Landström, H., Bruining, H., ... \& Hommel, U. (2006). Venture capitalists' decision to syndicate. Entrepreneurship Theory and Practice, 30(2), 131-153. http://dx.doi.org/10.1111/j.1540-6520.2006.00115.x

Mizruchi, M. S. (1992). The structure of corporate political action: Interfirm relations and their consequences. Cambridge, MA: Harvard University Press.

Mohr, J. J., \& Sengupta, S. (2002). Managing the paradox of inter-firm learning: the role of governance mechanisms. Journal of Business \& Industrial Marketing, 17(4), 282-301. http://dx.doi.org/10.1108/08858620210431688

Mowery, D. C., Oxley, J. E., \& Silverman, B. S. (1998). Technological overlap and interfirm cooperation: implications for the resource-based view of the firm. Research Policy, 27(5), 507-523. http://dx.doi.org/10.1016/S0048-7333(98)00066-3

Nahata, R. (2008). Venture capital reputation and investment performance. Journal of Financial Economics, 90(2), 127-151. http://dx.doi.org/10.1016/j.jfineco.2007.11.008 
Nahata, R., Hazarika, S., \& Tandon, K. (2014). Success in global venture capital investing: do institutional and cultural differences matter? Journal of Financial and Quantitative Analysis, 49(4), 1039-1070. http://dx.doi.org/10.1017/S0022109014000568

Nielsen, A. E., \& Thomsen, C. (2011). Sustainable development: the role of network communication. Corporate Social Responsibility and Environmental Management, 18(1), 1-10. http://dx.doi.org/10.1002/csr.221

Noyes, E., Brush, C., Hatten, K., \& Smith-Doerr, L. (2014). Firm network position and corporate venture capital investment. Journal of Small Business Management, 52(4), 713-731. http://dx.doi.org/10.1111/jsbm.12051

Paton, B. (2006). Collaboration among industry, civil society, and government for sustainability: a framework for identifying opportunities. Progress in Industrial Ecology, An International Journal, 3(1), 148-162. http://dx.doi.org/10.1504/PIE.2006.010046

Petzel, R., Archer, A. M., \& Fei, R. (2010). Collaboration for sustainability in a networked world. Procedia-Social and Behavioral Sciences, 2(4), 6597-6609. http://dx.doi.org/10.1016/j.sbspro.2010.04.070

Pezzey, J. (1992). Sustainability: an interdisciplinary guide. Environmental Values, 1(4), 321-362. http://dx.doi.org/10.3197/096327192776680034

Roeschmann, A. Z. (2014). Risk culture: what it is and how it affects an insurer's risk management. Risk Management and Insurance Review, 17(2), 277-296. http://dx.doi.org/10.1111/rmir.12025

Sahlman, W. A. (1990). The structure and governance of venture-capital organizations. Journal of Financial Economics, 27(2), 473-521. http://dx.doi.org/10.1016/0304-405X(90)90065-8

Sarkar, M. B., Echambadi, R., Cavusgil, S. T., \& Aulakh, P. S. (2001). The influence of complementarity, compatibility, and relationship capital on alliance performance. Journal of the Academy of Marketing Science, 29(4), 358-373. http://dx.doi.org/10.1177/03079450094216

Scott, W. R., \& Davis, G. F. (2003). Networks in and around organizations. Upper Saddle River, NJ: Pearson Prentice Hall.

Shane, S., \& Cable, D. (2002). Network ties, reputation, and the financing of new ventures. Management Science, 48(3), 364-381. http://dx.doi.org/10.1287/mnsc.48.3.364.7731

Sorenson, O., \& Stuart, T. E. (2001). Syndication networks and the spatial distribution of venture capital investments. American Journal of Sociology, 106(6), 1546-1588. http://dx.doi.org/10.1086/321301

Strandberg Consulting. (2013). Roadmap to sustainability: developing an industry association sustainability program for managers. Retrieved from http://corostrandberg.com/wp-content/uploads/2013/02/Industry-Association-Sustainability-Roadmap-2013. pdf

Stuart, T. E. (1998). Network positions and propensities to collaborate: an investigation of strategic alliance formation in a high-technology industry. Administrative Science Quarterly, 43(3), 668-698. http://dx.doi.org/10.2307/2393679

Stuart, T. E., Hoang, H., \& Hybels, R. C. (1999). Inter-organizational endorsements and the performance of

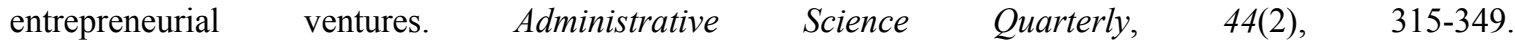
http://dx.doi.org/10.2307/2666998

Sydow, J., Van Well, B., \& Windeler, A. (1997). Networked networks: financial services networks in the context of their industry. International Studies of Management \& Organization, 27(4), 47-75. http://dx.doi.org/10.1080/00208825.1997.11656718

Teece, D. J. (1992). Competition, cooperation, and innovation: organizational arrangements for regimes of rapid technological progress. Journal of Economic Behavior \& Organization, 18(1), 1-25. http://dx.doi.org/10.1016/0167-2681(92)90050-L

Terjesen, S., Patel, P. C., Fiet, J. O., \& D'Souza, R. (2013). Normative rationality in venture capital financing. Technovation, 33(8), 255-264. http://dx.doi.org/10.1016/j.technovation.2012.10.004

Tsang, E. W. (1998). Motives for strategic alliance: a resource-based perspective. Scandinavian Journal of Management, 14(3), 207-221. http://dx.doi.org/10.1016/S0956-5221(97)00036-5

Tyebjee, T. T., \& Bruno, A. V. (1984). A model of venture capitalist investment activity. Management Science, 30(9), 1051-1066. http://dx.doi.org/10.1287/mnsc.30.9.1051

Tykvová, T. (2007). Who chooses whom? Syndication, skills and reputation. Review of Financial Economics, 
16(1), 5-28. http://dx.doi.org/10.1016/j.rfe.2005.10.001

United Nations Environment Programme (UNEP). (2015). Global trends in renewable energy investment 2015. UNEP Report. Retrieved from http://fs-unep-centre.org/publications/global-trends-renewable-energy-investment-2015

Venture Economics. (2009). VentureXpert database. Boston, MA: Thomson Reuters.

Wasserman, S. (1994). Social network analysis: methods and applications. Cambridge, UK: Cambridge University Press. http://dx.doi.org/10.1017/CBO9780511815478

Wright, M., \& Lockett, A. (2003). The structure and management of alliances: syndication in the venture capital $\begin{array}{lllll}\text { industry. Journal of } & \text { Management } & \text { Studies, } & \text { 40(8), } & \text { 2073-2102. }\end{array}$ http://dx.doi.org/10.1046/j.1467-6486.2003.00412.x

Young-Ybarra, C., \& Wiersema, M. (1999). Strategic flexibility in information technology alliances: the influence of transaction cost economics and social exchange theory. Organization Science, 10(4), 439-459. http://dx.doi.org/10.1287/orsc.10.4.439

Zhang, X., Feng, L., Zhu, R., \& Stanley, H. E. (2015). Applying temporal network analysis to the venture capital market. The European Physical Journal B, 88(10), 1-7. http://dx.doi.org/10.1140/epjb/e2015-60525-3

\section{Copyrights}

Copyright for this article is retained by the authors, with first publication rights granted to the journal.

This is an open-access article distributed under the terms and conditions of the Creative Commons Attribution license (http://creativecommons.org/licenses/by/3.0/). 